\title{
RELATIONSHIP OF ATTITUDE WITH STUDENT LEARNING ENVIRONMENT TOWARD PHYSICS
}

\author{
Dodi Setiawan Putra ${ }^{1 *}$, Ardy Irawan, Jelpapo Putra Yanto ${ }^{2}$, Mecco Mandala Putra ${ }^{3}$, \\ Syahrul Adli ${ }^{4}$, Utari Prisma Dewi ${ }^{5}$, Neng Ria Nasih ${ }^{6}$ \\ ${ }^{1,6,7}$ Physics Education Study Program, Universitas Jambi, Indonesia \\ ${ }^{2,4}$ Mathematics Education Study Program, Universitas Jambi, Indonesia \\ ${ }^{3}$ Chemistry Education Study Program, Universitas Jambi, Indonesia \\ ${ }^{5}$ History Education Study Program, Universitas Jambi, Indonesia \\ "Email: dodisetiawan158@ gmail.com
}

\author{
Website: http://jurnal.uin-antasari.ac.id/index.php/jtjik \\ Received: 9 March 2020; Accepted: 16 September 2020; Published: 15 December 2020
}

\begin{abstract}
The purpose of this study was to determine the description of student attitudes and learning environments towards physics and the relationship of student attitudes and learning environments towards physics at SMAN 6 Batang Hari. This type of research is quantitative using a correlational design with the instrument used is a questionnaire. The subjects of this study were 156 students from SMAN 6 Batang Hari. Quantitative data analysis techniques use descriptive and inferential statistics. The description for attitude is categorized as sufficient. While for the learning environment that is categorized good. The relationship between students' attitudes and learning environment towards physics is in the strong category with a pearson correlation of 0.719. Based on the results of SMAN 6 Batang Hari, the relationship between students' attitudes and the learning environment is strong for learning physics. Thus, positive student attitudes will be formed through a conducive learning environment.
\end{abstract}

Key Words: attitudes; learning environment; relationship; education; physics

\section{INTRODUCTION}

Education is an effort conducted to grow and develop the human resources potential, especially students, by guiding and facilitating their learning activities. Education plays an important role in improving the human resources quality (Astalini et al., 2019a; Darmaji, Kurniawan, \& Suryani, 2019). Education is a measure of a nation's advancement (Kurniawan et al., 2019; Maison et al., 2019). One of the education level that is attended by highly potential and competitive human resources is Senior High School (Astalini, Kurniawan, \& Sumaryanti, 2018). High curiosity is the spirit high school students possess in studying. Therefore, physics is one of the lessons that must be taught in order to support the students potentials in Senior High School.

There are several education levels in Indonesia. One of them is the senior high school level. Senior high school is a level of education that must be taken before proceeding to the next stage of higher education level (Astalini, Kurniawan, \& Putri, 2019). The students' potential can be developed through education. This can be achieved if it is supported by several factors such as the quality of teaching, the teaching methods, the teaching materials, the preparation of the material, and the curriculum. The achievement of this educational potential can be obtained through senior high school institutions. At 
this level, students have begun to gradually capable of controlling themselves to think scientifically. As the attempt to develop students' mindset, as the related subject, Physics would be necessary.

In fact, physics is one of the subjects that are considered complicated and avoided by some students because it requires persistence, thoroughness and lots of practice (Hardiyanti, Astalini, \& Kurniawan, 2018; Darmaji et al., 2018; Darmaji et al., 2019a) . The success of the teaching and learning activities in physics learning process can be measured by the success of students who take part in the activities (Kurniawan, Perdana, \& Kurniawan, 2019). In order to enable students in understanding the preliminary physics concepts easier, there needs to be innovation during lectures (Darmaji et al., 2019b). Learners perceive physics as a difficult subject during their school days and it gets even more difficult when they enter college. In the physics learning process, the student's attitude is very important.

Attitudes regarding with the ability to cope with emotions during the learning process play an important role in shaping human behavior (Astalini et al., 2019b). Because, students who have these views will show different attitudes compared to the student whose view is more positive during the learning process. Students' positive attitudes towards physics occur when students can understand deeper about the concepts of physics and make learning more effective in their environment (Astalini et al., 2019c).

Students who are not fond of physics can be observed from their attitudes and learning outcomes in physics. Positive or negative attitudes of students will affect learning in science and physics. However, it is known that negative attitudes towards certain subjects make learning difficult (Astalini et al., 2019d; Putra, Lumbantoruan, \& Samosir, 2019;
Putra et al., 2020). Lack of positive attitude that students have towards physics lessons causes various problems. One of the problems that occurs is the emergence of negative attitude towards physics subject. Less pleasant learning environment can also lead to negative attitudes of students such as boredom and lack of interest which inhibit the enthusiasm of students to learn.

According to Muliani (2015), the learning environment culture is all that is seen around students and the existence of factors that affect their development and behavior in carrying out their activities, as an effort to obtain changes in knowledge, attitudes and skills. With conducive learning environment culture, it will allow student to learn well. A comfortable learning environment can be put up by constructing innovation while teaching physics. Utilizing innovation in learning, one of which is through the use of social media into students' experience while learning something in class, teachers may also transfer new literacy which is part of student life outside of school so that students feel comfortable in the classroom with the adoption of something new (Glover \& Oliver, 2008).

According to Ashoumi (2016), a conducive learning climate is the foundation and a crucial factor that can provide its own attractiveness to support the learning process, on the other hand, an unpleasant learning climate will lead to boredom and decreasing interest and will ultimately inhibit students' enthusiasm for learning. This type of learning environment is necessary because physics lessons require high accuracy and focus so that what students learn can be absorbed and comprehended, so that it can assist students to achieve better learning outcomes.

Therefore, the atmosphere of the learning environment at school must be created optimally to help students feel comfortable to learn. A good student learning environment will support students' 
positive attitudes in physics. Students may achieve good academic result in an optimistic classroom setting and an environment in which they feel safe and comfortable (Suleman \& Hussein, 2014). The attitude of the students can determine the achievement of a good learning process in the classroom. A learning process that is supported by good student attitudes will run even more effectively. This is because students are the main objective of learning itself.

The purpose of this study was to determine the description and the relationship between students' attitudes and learning environment towards physics subjects at SMAN 6 Batang Hari.

\section{RESEARCH METHOD}

This research employ an associative quantitative study using a correlational research design. According to Yusuf (2017), correlational research is a method used to see the relationship between two or more variables. This research design was applied because it is in accordance with the research objectives to determine the description and relationship of students' attitudes with learning environment to physics subjects at SMAN 6 Batang Hari.

The subjects of this study were 156 students from SMAN 6 Batang Hari. The sampling technique applied in this study was purposive sampling. Purposive sampling refers to a sample that is carried out by taking the subject not based on strata, random or area but on the consideration of particular objectives (Heridiansyah, 2012). The reason for using this technique is that not all students study physics. So, the researchers only took some students from science class of SMAN 6 Batang Hari.

The instrument of this study is a questionnaire adopted from Darmawangsa's research (2018) which was valid and reliable with a Cronbach alpha value of 0.9 . This instrument uses a Likert scale. The scale consists of 5 points with the value of strongly agree as 5 , agree as 4 , neutral as 3 , disagree as 2 , and strongly disagree as 1. Each statement is a representative of each attitude indicator. Meanwhile, the learning environment questionnaire was adopted from Yana's (2014) research which was valid and reliable with a Cronbach alpha value of 0.85 . This questionnaire also uses a Likert scale consisting of 4 points, "always" with value the of 4 , "often" with value of 3 , "sometimes" with the value of 2 , and "never" with the value of 1 .

The research procedure started from the preparation stage, the proposal, formulating the problem and its variables. Then, literature review was conducted in order to collect supporting theories for the discussion in order to provide a description of the research conducted along with the necessary instruments. At the data collection stage, the questionnaires were distributed to 156 students at SMAN 6 Batang Hari. Based on the data, data analysis was carried out by filtering the appropriate data and coding the data.

The data analysis used was descriptive and inferential analysis with interval test and product moment. Description or presentation of large amounts of data that includes mean, mode, median, maximum and minimum can bw defined as descriptive statistics (Cohen et.al., 2007). Data were analyzed by using the SPSS 22 program to obtain the percentage, the frequency and the average. The range of relationship levels (correlation) is shown in Table 1.

Table 1. The relationship scale (Correlation)

\begin{tabular}{cl}
\hline Interval & Relationship Level Scale \\
\hline $0.80-1.000$ & Very Strong \\
$0.60-0.799$ & Strong \\
$0.40-0.599$ & Sufficient \\
$0.20-0.399$ & Weak \\
$0.00-0.199$ & Very Weak \\
\hline
\end{tabular}

(Source: Sunarto, 2015) 


\section{FINDINGS AND DISCUSSIONS}

The novelty of this research is the variable used to describe and determine the relationship between attitudes and the learning environment of students at SMAN 6 Batang Hari. The variables in this study are attitudes and learning environment.

1. Attitude

Attitude is constructed from personal experiences and social influences. Attitude is not something the student is born with, but it is constructed and shaped through experiences that have been passed.
Therefore, attitude can change according to the environment around the individual. In this study, 7 attitude indicators were reviewed which included 1) scientist normality, 2) social implications of physics, 3) adoption of a scientific attitude, 4) pleasure in learning physics, 5) investigation in physics, 6) interest in increasing physics learning duration and 7) interest to build a career in physics. The results of the attitude questionnaire that have been distributed at SMAN 6 Batang Hari can be seen on Table 2 .

Table 2 Student's attitude toward Physics Subject at SMAN 6 Batang Hari

\begin{tabular}{|c|c|c|c|c|c|c|c|}
\hline \multicolumn{3}{|c|}{ Classification } & Mean & Median & Min & Max & $\%$ \\
\hline Interval & Category & Total & & & & & \\
\hline $54.00-97.20$ & Very Poor & 0 & & & & & 0.0 \\
\hline $97.30-140.4$ & Poor & 6 & & & & & 3.8 \\
\hline $140.5-183.6$ & Sufficient & 105 & 180.67 & 179.5 & 122 & 241 & 67.3 \\
\hline $183.7-226.8$ & Good & 37 & & & & & 23.7 \\
\hline $226.9-270.0$ & Very Good & 8 & & & & & 5.1 \\
\hline Total & & 156 & & & & & \\
\hline
\end{tabular}

In Table 2, the dominant of student response was categorized as good with the percentage of $67.3 \%$ (105 of 156 students). In this case, students still hesitate to act like a scientist with all kinds of life and their habits in doing physics tasks in class. The attitude of students who like to ask questions after trying to find solutions or answers shows that students' curiosity is very high in the investigations that they are doing (Astalini, Kurniawan, \& Anggraini, 2019). In accordance with the opinion of Kurniawan, Perdana \& Kurniasari (2018) that high curiosity is one of the positive attitudes a scientist has. This can be seen at SMAN 6 Batang Hari, the habit of students who are curious about new things will raise questions in their minds and motivate them to discover the answer (Astalini et al., 2019; Astalini, Kurniawan, \& Anggraini, 2019; Kurniawan \& Susanti, 2018).

Meanwhile, $3.8 \%$ of students were in the poor category. Based on this, if students already have a scientist and scientific attitude regarding with learning physics, then students will settle down and continue their careers in physics as well (Astalini et al., 2019; Juan, 2016). In a career of physics, students' interest in the subject itself must also be considered because interest greatly affects student career achievement and personal life (Izzet \& Arslan, 2015).

From the opinions and results above, it can be seen that students who like physics will show a positive attitude towards physics. The more positive the attitude, the more positive the student's performance in all activities (Khumaeroh et al., 2017; Putra \& Wiza, 2019). On the contrary, students who dislike physics will show negative attitudes towards physics (Wiza \& Putra, 2019). It turns out as the biggest challenge for physics teachers to get students to show a positive and active attitude when studying physics, so that they attain good learning outcomes.

\section{Learning environment}

The learning environment is a place for teaching and learning activities that 
possibly determine behavior directly or indirectly. In this study, 9 indicators of the learning environment were reviewed which included 1) teaching methods, 2) curriculum, 3) teacher-student relation, 4) student-student relation, 5) lesson and its duration, 6) school discipline, 7) school standard, 8) the infrastructure condition and 9) homework. The results of the learning environment questionnaire that have been distributed at SMAN 6 Batang Hari can be seen on Table 3 .

Table 3. Learning Environmeny of SMAN 6 Batang Hari

\begin{tabular}{|c|c|c|c|c|c|c|c|}
\hline \multicolumn{3}{|c|}{ Classification } & Mean & Median & Min & Max & $\%$ \\
\hline Interval & Category & Total & & & & & \\
\hline $35.00-63.00$ & Very Poor & 0 & & & & & 0 \\
\hline $63.10-91.00$ & Poor & 4 & & & & & 2.6 \\
\hline $91.10-119.0$ & Sufficient & 26 & 127.44 & 127 & 91 & 127 & 16.6 \\
\hline $119.1-147.0$ & Good & 112 & & & & & 71.8 \\
\hline $147.1-175.0$ & Very good & 14 & & & & & 9.0 \\
\hline Total & & 156 & & & & & \\
\hline
\end{tabular}

On Table 3, the student learning environment at SMAN 6 Batang Hari is dominant in the good category of $71.8 \%$ (112 out of 156 students). This indicates that the atmosphere of the student learning environment at SMAN 6 Batang Hari is conducive. The atmosphere of a conducive learning environment will have a positive impact on students so that it will affect the subjects they study. One of the factor that results good or bad learning in the classroom comes from the teacher (Asrial et al., 2019). The relationship between teachers and students must be good. Prospective teachers are required to have good pedagogical competence (Asrial et al., 2019; Darmaji et al., 2018).

Furthermore, $2.6 \%$ of students are in the poor category. The teacher is one of the facilitators who influence student satisfaction, attitudes, achievement, persistence and build learning environment so that students can be active in decision making, communication patterns, results, persistence, lesson content, and satisfaction (Erdiansyah et al., 2019). If a teacher is motivated and positive, they will likely have a beneficial impact on their students as well. It is crucial for a teacher to recognize this cause and effect in order to understand how to manage their class to create a better learning environment (Hannah, 2013). Therefore, qualified teachers will be capable of designing a good learning environment in the classroom.

Based on the statistical analysis above at SMAN 6 Batang Hari related to the attitudes and learning environment of students towards physics subjects, the next step was to determine the relationship between students' attitudes and learning environment towards physics subjects by employing the product moment correlation test. The results for SMAN 6 Batang Hari is shown in Table 4.

Table 4. Relationship between attitude and learning environment towards at SMAN 6 Batang Hari

\begin{tabular}{llc}
\hline & & $\begin{array}{l}\text { Learning } \\
\text { Environment }\end{array}$ \\
\hline Attitude & Pearson & .719 \\
& Correlation & .018 \\
\hline & Sig. (2-tailed) &
\end{tabular}

From the results of the product moment correlation test above, it was found that there was a relationship between the attitudes with learning environment of students towards physics subjects at SMAN 6 Batang Hari in the strong category with a Pearson Correlation value of 0.719 . In accordance with the provisions of the significance value of Sig. (2-tailed) $<0.05$ implies that there is a relationship between variables (Kadir, 2015). 
If schools really play a huge role in guiding the nation's next generation who will turn into successful, talented and ethical people, then every precaution must be taken seriously to ensure that the learning environment as one of the reasons that boost students to grow and develop (Hannah, 2013). According to Aini \& Taman (2012), if the condition of the learning environment is very supportive, students will be more enthusiastic throughout the learning process. For example, if the atmosphere is safe and comfortable, the students can absorb what their teacher deliver.

In constrast, if the environmental condition is less supportive in the learning process, the students will feel uncomfortable which may impact student attitudes. Therefore, the atmosphere of the learning environment at school must be made as optimal as possible to assist students so they can feel comfortable and realaxed to learn. A good student learning environment will enhance students' positive attitudes in physics. The attitude of the students can determine the achievement of a good learning process in the classroom.

A learning process that is supported by good student attitudes will run more effectively so that physics knowledge and learning material will be easily absorbed and comprehended by students which possibly improve learning outcomes. This is because students are the main goal of learning itself. With a good learning environment, students will gain readiness and pay attention to their preparation to learn.

\section{CONCLUSION}

This research has obtained descriptions of students 'attitudes and learning environment as well as tests of the relationship between students' attitudes and learning environment towards physics subjects at SMAN 6 Batang Hari. The results of the attitude description obtained are in the sufficient category. Meanwhile, the description of the learning environment at SMAN 6 Batang Hari is in a good category. From the results of the correlation test obtained, it is known that there is a relationship between students' attitudes and learning environment towards physics subjects. The relationship between students' attitudes and learning environment towards physics subjects at SMAN 6 Batang Hari is strong. The learning environment is closely related to attitude. This indicates that if the student's learning environment is good, the students will show a positive attitude in physics.

\section{REFERENCES}

Aini, P, N., \& Taman, A. (2012). Pengaruh Kemandirian Belajar danLingkungan Belajar Siswa terhadap Prestasi Belajar Akuntansi Siswa Kelas XI IPS SMA Negeri 1 Sewon Bantul Tahun Ajaran 2010/2011. Jurnal Pendidikan Akuntansi Indonesia, 1(1), 48-65.

Ashoumi, H. (2016). Pendayagunaan Lingkungan Sekolah Religius untuk Memaksimalkan Pencapaian Kurikulum PAI. DINAMIKA, 1(1), 35-50.

Asrial, A., Syahrial, S., Kurniawan, D, A., Chan, F., Nugoroho, P., Pratama, R, A., \& Septiasari, R. (2019). Identification: The Effect Of Mathematical Competence On Pedagogic Competency Of Prospective Teacher, Humanities \& Social Sciences Reviews (HSSR), 7(4), 85-92.

Asrial, A., Syahrial, S., Kurniawan, D. A., \& Amalina, N. (2019). Analisis Hubungan Kompetensi Bahasa Indonesia Terhadap Kompetensi Pedagogik Mahasiswa Pendidikan Guru Sekolah Dasar. Premiere Educandum: Jurnal Pendidikan Dasar dan Pembelajaran, 9(1), 1-8. 
Astalini A., Kurniawan, D, A., Darmaji, D., Sholihah, L, R., \& Perdana, R. (2019a). Characteristics of Students' Attitude to Physics in Muaro Jambi High School. Humanities \& Social Sciences Reviews (HSSR), 7(2), 9199.

Astalini, A., Kurniawan, D. A., \& Sumaryanti, S. (2018). Sikap Siswa Terhadap Pelajaran Fisika di SMAN Kabupaten Batanghari, JIPF (Jurnal Ilmu Pendidikan Fisika), 3(2), 59-64.

Astalini, A., Darmaji D., Kurniawan, D. A., \& Destianti, A. (2019b). Description of the Dimensions Attitudes towards Science in Junior High School at Muaro Jambi.International Journal of Sciences: Basic and Applied Research (IJSBAR), 47(1), 1-11.

Astalini, A., Kurniawan, D, A., \& Anggraini, L. (2019c). Correlation between confidence with attitude toward science in secondary school in Indonesia. Beder Scientific Journal of Education Sciences (BJES), 20(1), 30-45.

Astalini, A., Kurniawan, D, A., Kurniawan, N., \& Anggraini, L. (2019d). Evaluation of Student's Attitude Toward Science in Indonesia. Open Journal for Educational Research (OJER), 3(1), 1-12.

Astalini, A., Kurniawan, D, A., Perdana, R., \& Pathoni, H. (2019e). Identifikasi Sikap Peserta Didik terhadap Mata Pelajaran Fisika di Sekolah Menengah Atas Negeri 5 Kota Jambi, UPEJ Unnes Physics Education Journal, 8(1), 34-43.

Astalini, A., Kurniawan, D. A., \& Putri, A, D. (2019). Identifikasi Sikap Implikasi Sosial dari IPA, Ketertarikan Menambah Waktu Belajar IPA, dan Ketertarikan Berkarir Dibidang IPA Siswa SMP Se-Kabupaten Muaro Jambi. Jurnal
Tarbiyah : Jurnal Ilmiah Kependidikan, 7(2), 93-108.

Astalini, A., Kurniawan, D. A., Sari, D. K., \& Kurniawan, W. (2019f). Description of Scientific Normality, Attitudes of Investigation and Interested Career On Physics in Senior High School. JIPF (Jurnal Ilmu Pendidikan Fisika), 4(2), 56-63.

Cohen, L., Manion, L., \& Marrison, K. (2007). Research Methods in Education. New York: Routledge.

Darmaji, D., Astalini, A., Kurniawan, D., \& Perdana, R. (2019a). A study relationship attitude toward physics, motivation, and character discipline students senior high school, in Indonesia. International Journal of Learning and Teaching, 11(3), 99109.

Darmaji, D., Kurniawan, D. A., \& Suryani, A. (2019). Effectiveness of Basic Physics II Practicum Guidelines Based on Science Process Skills, JIPF (Jurnal Ilmu Pendidikan Fisika), 4(1), 1-7.

Darmaji, D., Kurniawan, D. A., Astalini, A., \& Nasih, N. R. (2019b). Persepsi Mahasiswa pada Penuntun Praktikum Fisika Dasar II Berbasis Mobile Learning. Jurnal Pendidikan: Teori, Penelitian, dan Pengembangan, 4(4), 516-523.

Darmaji, D., Kurniawan, D. A., Parasdila, H., \& Irdianti, I. (2018). Deskripsi Keterampilan Proses Sains Mahasiswa pada Materi Termodinamika. Berkala Ilmiah Pendidikan Fisika, 6(3), 345-353.

Darmawangsa, R. (2018). Pengembangan Instrumen Sikap Siswa Sekolah Menengah Atas terhadap Mata Pelajaran Fisika, Jurnal Pendidikan Fisika-Journal of Physics Education, 6(1), 107-114.

Ediansyah, E., Kurniawan, D, A., Salamah, S., \& Perdana, R. (2019). Investigation of Problem Based Learning: Process of Understanding 
The Concepts and Independence Learning on Research Statistics Subject, Humanities \& Social Sciences Reviews (HSSR), 7(5), 111.

Glover, I., \& Oliver, A. (2008). Hybridisation of social networking and learning environments, Paper presented at the World Conference on Educational Multimedia, Hypermedia and Telecommunications, Vienna, Austria.

Hannah, R. (2013). "The Effect of Classroom Environment on Student Learning". Honors Theses. Paper 2375.

Hardiyanti, K., Astalini, A., \& Kurniawan, D, A. (2018). Sikap Siswa Terhadap Mata Pelajaran Fisika Di SMA Negeri 5 Muaro Jambi. EduFisika: Jurnal Pendidikan Fisika, 3(2), 1-12.

Heridiansyah, J. (2012). Pengaruh Advertising Terhadap Pembentukan Brand Awareness Serta Dampaknya Pada Keputusan Pembelian Produk Kecap Pedas ABC (Studi Kasus Pada Konsumen Pengguna Kecap Pedas ABC di Kota Semarang). Jurnal STIE Semarang, 4(2), 53-73.

İzzet Kurbanoğlu, N., \& Arslan, S. (2015). High school students' educational and career interest (sciencetechnology-mathematics) and career adaptabilities. Australian Journal of Career Development, 24(3), 166172.

Juan, A, R. (2016). Does It Matter Whether Students Enjoy Learning Science? Exploring Student Attitudes towards Science, South Africa. Human Sciences Reseach Council, 1(1), 1-6.

Kadir. (2015). Statistika Terapan. Jakarta: PT Grafindo Persada.

Khumaeroh, S, U., Susongko, P., \& Rokhman, M, S. (2017). Penyusunan Skala Sikap Peserta Didik Terhadap Matematika Dengan Penerapan Model Rasch, JPMP, 1(1), 43-52
Kurniawan, D. A., \& Susanti, A. (2018). Attitudes of College Students on the Subject of Mathematical Physics III in Physics Education Program of Jambi University. The Educational Review, USA, 2(11), 505-513.

Kurniawan, D. A., Perdana, R., \& Kurniasari, D. (2018). Identification of Student Attitudes toward Physics Learning at Batanghari District High School. The Educational Review, USA, 2(9), 475-484.

Kurniawan, D. A., Perdana, R., \& Kurniawan, W. (2019). Identification Attitudes of Learners on Physics Subjects. Journal of Educational Science and Technology (EST), 5(1), 56-63.

Maison, M., Darmaji, D., Astalini, A., Kurniawan, D, A., \& Indrawati, P, S. (2019). Science Process Skills And Motivation, Humanities \& Social Sciences Reviews (HSSR), 7(5), 4856.

Muliani, S., \& Munir, A. R. (2015). Motivasi, komitmen, dan budaya lingkungan belajar terhadap prestas belajar peserta kursus TOEFL preparation pada pusat bahasa Universitas

Hasanuddin. JurnalAnalisis, 4(2), 190-195.

Putra, D. S., Lumbantoruan, A., \& Samosir, S. C. (2019). Deskripsi Sikap Siswa: Adopsi Sikap Ilmiah, Ketertarikan Memperbanyak Waktu Belajar Fisika dan Ketertarikan Berkarir di Bidang Fisika. Tarbiyah: Jurnal Ilmiah Kependidikan, 8(2), 91-100.

Putra, D. S., Piscessari, S., Farna, E. R., Yovinda, A. N., Nugroho, L. B., Samosir, S. C., \& Lumbantoruan, A. (2020). Sikap Implikasi Sosial, Adopsi Sikap Ilmiah dan Ketertarikan Berkarir dibidang Fisika Sekolah Menengah Atas. Jurnal Pendidikan, 8(1), 9-18. 
Putra, D. S., \& Wiza, O. H. (2019). Analisis Sikap Siswa Terhadap Mata Pelajaran Fisika di SMA Ferdy Ferry Putra Kota Jambi. UPEJ Unnes Physics Education Journal, 8(3), 299-311.

Suleman, Q., \& Hussain, I. (2014). Effects of classroom physical environment on the academic achievement scores of secondary school students in kohat division, Pakistan. International Journal of Learning \& Development, 4(1), 71-82.

Yana, E., \& Jayanti, R. P. (2014). Pengaruh Lingkungan Sekolah dan Sikap Peserta Didik terhadap Hasil Belajar Peserta Didik pada Mata Pelajaran
Ekonomi. Edunomic Jurnal Pendidikan Ekonomi, 2(2), 88-94.

Wiza, O. H., \& Putra, D. S. (2019). Sikap Implikasi Sosial, Kesenangan dan Ketertarikan Berkarir di Bidang IPA di SMPN 17 Batanghari. PSEJ (Pancasakti Science Education Journal), 4(2), 121-127.

Yusuf. A. Muri. 2017. Metode Penelitian Kuantitatif, Kualitatif, \& Penelitian Gabungan. Jakarta: Kencana. 